\title{
実践研究
}

\section{2 次元形成萌芽期にあるH君の労働特性}

\author{
小 林 勝 年
}

\begin{abstract}
「可逆操作の高次化における階層一段階理論」によって発達年齢 2 歳前半の 2 次元形成萌 芽期と位置づけられた成人知的障害者 (30 歳)について過去 12 年間にわたる指導記録におけ る特徵的なエピソードを類型化することによって、以下 6 つの労働特性が導き出された。(1) 作業行動の中断、(2)作業課題を理解することの困難さ、(3)作業集団における自己中心的対人 関与、(4)手の操作から道具の操作への中間的段階、(5)作業成果に対する自己評価の未熟さ、 6労働活動における直接的動機づけ。このような労働に即した発達特性を生む要因として、 この発達段階では反応が固定化しやすく労働活動を営むうえでの基本要素である「目標」「方 法」「成果」という 3 要素が泥在化した「過程的行為」に向かう傾向にあることが指摘され た。したがって、上記の 3 要素が円滑に連関されるのを援助していくことが労働保障におけ る前提と考えられた。
\end{abstract}

キー・ワード : 2 次元形成萌芽期 成人知的障害者 過程的行為

\section{I . 問 題}

1988 年の障害者雇用促進法の一部改正は重度知的 障害者にも一般就労の可能性を拡大する契機ともなっ たが、その際に労働活動の主体者である彼らの発達段 階と各々の労働特性との関連を明らかにすることが雇 用拡大への前提作業となろう。本研究においては現在 30 歳で新版 $\mathrm{K}$ 式発達検査にて 2 歳 1 力月と診断され た $\mathrm{H}$ 君の過去 12 年間にわたる授産施設での作業指導 の成果を検討して発達年歯 2 歳前後の成人知的障害者 における労働の意味・労働特性を明らかにすることを 目的とした。

なお、発達水準の判定においては生活年齢からの影 響としての発達的蓄積物や各発達領域のずれなど成人 特有の問題にも対処でき得るという理由から、姿勢・ 運動系・末端投射活動系、感覚系、情動ないし交流の 系などについて統合的にとらえた「可逆操作の高次化 における階層一段階理論」(田中, 19804) にもとづい た。

神户市役所

\section{II. 方 法 \\ 1. 対 象}

$\mathrm{H}$ 君 (1994 年現在, 30 歳) は在胎期間 10 力月、出生 時の体重 2,900 g、正常分媿で誕生している。しかし、 生後 5 力月の時入浴中にひきつけをおこし近所の医療 機関で治療を受けたが 1 歳時に「てんかん」と診断さ れた。なお、その後は八イハイ 9 力月、歩行 14 力月、 発話 12 力月と順調に発達している。4 歳 8 力月で精神 薄弱児通所施設に入所し 14 歳で転園するが 19 歳にな るまで同種の施設に通っていた。その後は現在在籍し ている通所授産施設においてアルミ缶つぶしやポリ袋

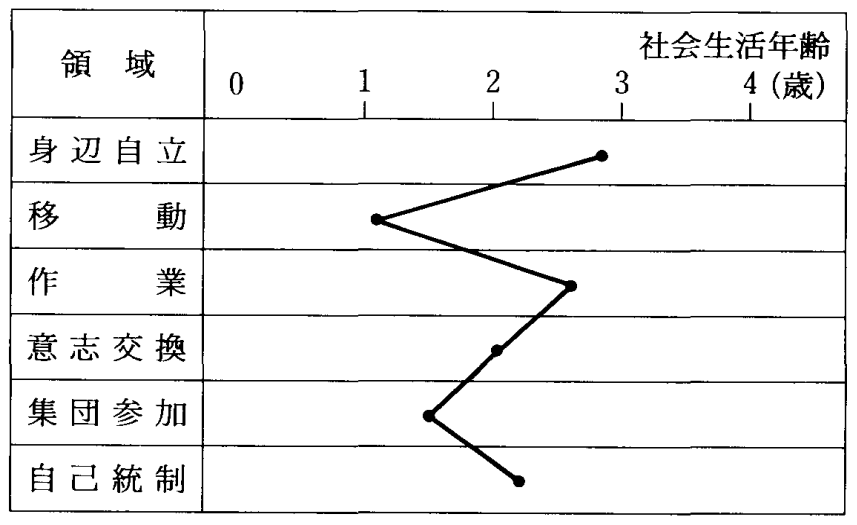

Fig. 1 領域別社会生活年齢 
Table 1 O 園の日 課 表

\begin{tabular}{|c|c|c|c|c|c|c|c|c|c|c|}
\hline \multirow{2}{*}{$\begin{array}{c}9: 00 \\
\text { 登 }\end{array}$} & \multicolumn{2}{|c|}{$9: 30$} & $10: 30$ & \multicolumn{2}{|c|}{$12: 00 \quad 12: 30$} & 15 & \multicolumn{2}{|c|}{$: 152: 30$} & $3: 30$ & $4: 00$ \\
\hline & 衣 & $\begin{array}{c}\text { 朝 礼 } \\
\text { 体 操 } \\
\text { マラソン }\end{array}$ & 作 業 & $\begin{array}{l}\text { 給 } \\
\text { 食 }\end{array}$ & $\begin{array}{l}\text { 後片付け } \\
\text { 雾磨き } \\
\text { 休 㮩 }\end{array}$ & 作 業 & $\begin{array}{l}\text { 休 } \\
\text { 媳 }\end{array}$ & 作 業 & $\begin{array}{l}\text { 更 } \\
\text { 衣 }\end{array}$ & $\begin{array}{l}\text { 降 } \\
\text { 園 }\end{array}$ \\
\hline
\end{tabular}

の袋詰め等の軽作業に従事してきた。

\section{2. 障害の状況}

障害の状況については、投薬による副作用として「側 弯症」が認められ、文部省「重症心身障害児」研究班 の区分では区分 10 (身体障害：日常生活が不自由なが らもできる；知能障害：IQ 25 以下）に該当する。

次に、S-M 社会生活能力検查の結果 (1994 年 3 月実 施）上り社会生活年齢 2 歳 2 力月、社会生活指数 15 で あったが、各領域の結果はFig. 1 に示した通りであ る。

また、西村 $\left(1970^{2)}\right)$ の行動発達段階によれば、「自 分の靴を靴箱から出してはく」、相手を見つけて肩に 手をかける」「給食時食堂までの移動が一人でできる」 などの行動観察結果より水準 $\mathrm{B}$ 〈段階IV〉(目的志向性, 自発性を伴った “狭義” の行動発達水準）に該当する。

\section{3 . 分析資料}

発達段階の分析には 1992 年 10 月 15 日〜 10 月 22 日において筆者と担当指導員 2 名による行動観察及び 課題反応の結果より得られた記録を用いた。また、労 働特性についての検討は入所から現在までにわたる約 12 年間のケース記録・保護者からの聴取記録を分析資 料とした。

\section{4 . 施設概要}

定員 50 名の通所型授産施設で日課プログラムは Table 1のようになっている。作業班は現在 3 つに分 れているが、入所者の状況や授産科目の変更に伴って 毎年作業班や構成メンバーに変化がある。現在取り組 まれている作業種目は、ポリ袋製造、紙袋・紙箱加工、 アルミ午のリサイクル、木工、農耕作業である。

\section{III．結果と考察}

\section{1.「可逆操作の高次化における階層一段階理論」} にもとづく発達的特徵

田中・田中 $\left(1984^{5)}\right)$ と田中 $\left(1987^{6)}\right)$ は「可逆操作 の高次化における階層一段階理論」において、基本連 関・上部連関・下部連関・散逸連関という 4 つの局面 における特徴的変化に着目した発達過程の分析方法を 提示している。本研究はこの方法に基づいてまず $\mathrm{H}$ 君
の行動特徵について検討した。

〈下部連関〉（姿勢・運動系の発達レベル）

(1) 起立姿勢...側弯状態の上体を支えるため両ひざが 大きく曲がり重心が一挙にそこへ集中するため両足 を $20 〜 30 \mathrm{~cm}$ ほど離していなければ起立保持がで きない。

(2) 片足立ち…右足を挙げる場合反対の左手で左ひざ をつかみ右手を前に突き出しながら右足のつま先を 上に向けてバランスをとる。重心制御が困難な姿勢 をとりながらもこうして重心を一定に保とうとした 点は、2 次元形成期（2 歳半ごろ）の特徵と言える。

(3) 歩行…立位姿勢の不安定は歩行においてもバラン スを欠く結果となり、特に坂道や狭い道路での移動 中は転倒し易い。

(4) 自転車のペダルこぎ‥停止中の自転車に乗るが、 ペダルを踏んだままで回転することはできない。し ばらく、両足の相反する動きからくる上下の可逆的 な運動を繰り返すことを楽しんでいた。

(5) 足踏み…立位での姿勢がかなり前傾であることか ら、その場での足踏みは困難となる。2〜3 歩ならで きるが、その以上は前方へ進んでしまい歩行動作と なる。

〈基本連関〉（末端投射活動系の発達レベル）

(1) 指の㐿伸 $\cdots \mathrm{V}$ サインのモデルを示すと模做がで きる。また、キツネのモデル（人差し指と小指を立 て中指・薬指を親指と合わせる）を示すと「コウ？ コウ?」と何度も尋ねながら人差し指のみ伸ばした り曲げたりしていた。これは模倣と修正を基礎とす る活動の萌芽期として 2 歳後半頃の特徵的行動と類 似している。

(2) 粘土による表現‥(1)加工したものを量産する、(2) 粘土を持つ手と道具を持つ手が分化する、(3)掌を回 転させる動作ができる、(4)作った物に命名する、(5) 一心不乱に作品作りに取り組むなど 3 歳前半からの 2 次元構成の発展期に該当する行動が認められた。

(3) 描画…意図を持って描こうとする「円錯画」の段 階であるが、(1)最初描いたものに続けてまた描く、 (2)一定の形の中で意図的な表現を試みる、(3)自由画 


\section{2 次元形成萌芽期にあるH君の労働特性}

は外転円錯になりやすいなど 2 歳前半の特徴と重な る面が認められた。

(4) 積み木構成…(1) 2 次元の連続対称、(2) 2 次元の連 続非対称、(3) 2 次元の不連続対称、(4)斜方形とずれ を含む 2 次元の不連続対称、という 4 課題に対して、 2 次元の不連続対称課題のみモデルどおりに完成す ることができた(Fig. 2 参照)。これは生活年齢が高 くなるにつれて対称性の操作レベルが高まる傾向に ある (白石, $\left.1987^{3}\right)$ ) ということと操作数が 3 つであ るため縦・横の 2 次元を同時に正中線上で処理でき たためと考えられる。なお、他の反応結果も含めて 考えると『田中による「1 次元から 2 次元形成期」へ の移行期』(田中，19887)）と判断される。

（5）配分…(1)赤い積み木 8 個を 2 枚の黄色い皿に入れ 分ける課題：一方に 7 個もう一方に 1 個入れた、(2) 赤い積み木 8 個を赤い皿と白い皿に入れ分ける課 題：赤い皿に 6 個、白い皿に 2 個入れ分けた、(3)白 い積み木 4 個と赤い積み木 4 個を混ぜたものを 2 枚 の黄色い皿に入れ分ける課題：一方の血に 8 個全部 入れた、(4)白い積み木 4 個と赤い積み木 4 個を混ぜ たものを赤い皿と白い皿に入れ分ける課題：赤い皿

(1)

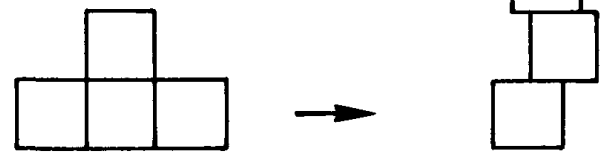

(2)

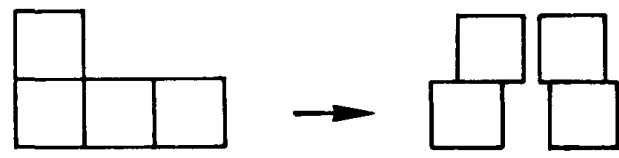

(3)
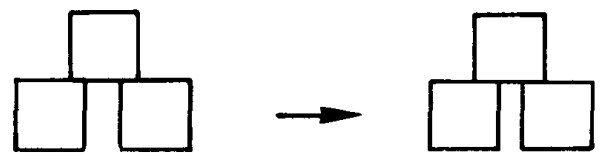

(4)

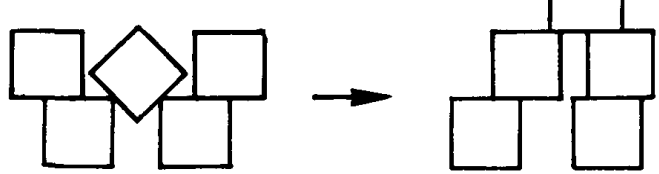

Fig. 2 積木構成課題に対する反応 （左はモデル，右はH君の作品）
に 2 個（赤 1 , 白 1 ）白い皿に 6 個（赤 3 , 白 3 ）を入 れ分けた。

以上の結果よりどちらか一方にたくさん入れるとい う方略を基本的には持ちながらも、色の対比によっ てそれが䋧和されたり強められたりする 2 歳前半期 の特徵が認められた。

(6) 弁別 $\cdots$ 儊 $13 \mathrm{~cm}$ 、横 $18 \mathrm{~cm}$ の白色台紙に直径 $4 \mathrm{~cm}$ と $5.5 \mathrm{~cm}$ の赤色円がはってある刺激版を用い、左 右上下に位置を変えながら「どっちが大きい?」の 問いを与えたところいずれも『大』を指すことがで きた。同様に幅 $2 \mathrm{~cm}$ で長さ $4 \mathrm{~cm}$ と $7 \mathrm{~cm}$ の赤色 テープで「どっちが長い？」と踌ねると横向きの変 化には『長』を指すことはできたが、縦の変化に対 してはいずれも右側のテープを指さした。よって、 大・小を基本とした区別的 2 次元が形成されようと する初期の過程にあることが示された。

〈上部連関〉(感覚系, 情動ないし交流の系の発達レ ベル)

(1)指さしができる。(2)同じ発語にたいしてアクセン トに変化をもたせて伝える。(3)「オイ」という呼びか けや「オバチャン」「オッチャン」などの人称を多用 する。(4)自分の姓名については名字と名前を区切って 伝えることができるが年齢については正しく答えられ ない。

衣類、持ち物、食料品などについての名詞と「ブー ン」「キューキュー」「デェーン」などの擬声語によ る動詞的表現を中心とした 1 語文使用がほとんどで、 1 次元可逆操作期 (1 歳半頃) の発達的特徴と類似して いる。

〈散逸連関〉（下部連関・基本連関・上部連関の各連 関における動的協応性）

追加配分課題として、5つのアメを 3 人に分ける課 題：父の皿に 1つ、母の四に 1つ、自分の皿に 3 つを 取って入れた。次に、兄の皿を 1 枚加え配分するよう に言うと自分の皿から 2 個取り出して入れた。さらに、 祖母の皿を 1 枚追加すると 1 度は 2 圆入れてある兄の 血から 1 個を取り出して入れ換えようとしたが、「イヤ イヤ!」と言って配分を拒否し血を突き返した。この ように基本的には自分に最大の量を確保しようとする が、新しく加わった人を尊重しつつも矛盾の解決を図 ろうとした行為は「自我の拡大」を特徴とする 2 次元 形成萌芽期 (2 歳前半) の特徴と一致する。また、友達 との間に「つねる」「たたく」などのトラブルが頻発 する一方で、特定の職員に甘えたがることから 1 次元 可逆操作期 (1 歳後半) に特徵的な密着的人間関係を示 
していることが認められた。

以上 4 つの局面における発達的特徵を調べてみると 基本的には 2 次元形成期に向かっているものの、下部 連関での側弯姿勢が活動の拡がりを制限していたり、 言語発達が 1 語文使用の段階にとどまっていることが 変化を受けとめて活動を再構成していく力を弱めた り、対人関係を希薄にさせていることがわかった。

\section{2. 指道記録による H 君の労動特性と発達的特徵 との関連}

過去 12 年間の指導記録の中では、(1)作業準備を積極 的に行うようになった、(2)作業の開始と終了をほぼ理 解できるようになった、(3)課題を遂行しようとする意 欲が高まった、などの指導成果が確認されている一方、 自力で作業遂行することへの困難性や幾種かのトラブ ルが毎年のように記されていた。そこで、指導員は自 らの対忘のあり方を反省したり作業課題の変更や作業 集団の検討など $\mathrm{H}$ 君の労働参加に向けた様々な持続 的な取り組みを実践してきた。しかし、この間に H 君 にまつわる問題は変わらず本人の労働特性としてとら え直す段階にまで到達したのである。以下頻繁に報告 されてきた類似のエピソードをまとめると6 項目に集 約された。

(1) 作業行動の中断

・製品の運搬作業をしていたが、途中から運ぶのをや めて倉庫の入り口にあるインターフォンで遊びだす (1982.3.22)。

・箱折りをしていたが、途中から指導員 (以下 T と略 す)にいたずらを始める。Tのボールペンを奪って みたり、靴ひもをほどいてみたりますますエスカ レートしていた (1981.9.19)。

・Tのそばに座って箱の折り目つけ作業をしていた が、Tが離席すると「イヤヤ!」と言って作業を拒 否して材料を投げた（1982.4.1）。

・作業中、カラスが鳴いているのに気が付いて「カア一 カアーヤ」と $\mathrm{T} に$ 告げては笑い出す。カラスを追っ てベランダに出たまま作業室には帰ってこなかった

(1982.5.7)。

(2) 作業課題を理解することの困難さ

・紙袋のひも通しをするが、入れる方向を変えたり同 じ穴に 2 回通すなどの間違いが絶えない。本人に誤 りを指摘すると一応納得するが再び同じ間違いをす ぐに繰り返した（1981.4.28）。

・畑の草取り作業をする。しばらくは草取りをしてい たが隣に生えていたダイコンやイモを抜いてしま う。Tが注意して作物が植えられていない所の草取
りを頼むが再びダイコンを抜こうとした (1983.9.8)。

・ポリ袋の製品を作業室から倉庫へ運ぶ課題に取り組 んだ。自分からカゴを取り出して製品をいれるなど 準備段階から意欲的であったが運ぶ製品がなくなっ てしまうと材料が入っている包みや他の荷物までも 運搬用の力ゴに入れて運んでしまった。Tがあわて て、「これは運ばなくてもいいんや！」と言って止め るが、納得できず入り口付近に立ち止まる (1986.10.22)。

・かまを持って草刚りをしていたが、いつの間にか近 くに植えてあるナスやトウガラシを切ってしまって いた。友達から非難されるが、本人は知らん顔で切 り続けた（1986.10.22）。

・作物の水やりをしていたが、同じ場所に立ったまま 動こうとせず、結局盛土が流されて根が地表に表れ てきた。本人はそれにもかかわらず、ずっと同じ姿 勢で水やりをし続けていた（1987.9.9）。

(3) 作業集団における自己中心的対人関与

・しばらく一人で作業をしていたが、テーブルの上に ある材料を独占して材料をとりにくる仲間に一つず つ渡していったり、棚の上においてある袋をだれか がとりにいこうとすると先回りしてわざわざ自分か ら手渡そうとするなど自分の作業課題はそっちのけ で周囲の者に干渉しようとしていた（1986.5.12）。

・土運び。初め各々がスコップでバケツに土を入れて 運ぶようにしていたが、いつの間にか土を掘り起こ す場所を占領して友達のバケツに次々と入れようと していた。数人から土入れが遅いのでその場を譲る ように言われたが、本人は頑としてその場から動こ うとしなかった (1986.10.28)。

・箱折りをしていたが、友達が完成された紙箱を一つ 一つ積み上げては 12 個ずつ結束しているのに目が 留まって自分も同様な作業がしたいと訴える。周囲 の箱をあたりかまわず集めては重ね、「タカイヨータ カイヨー」と T に自慢げに言い、多少興奮ぎみ。や がて 12 個の単位になっていないことや重ねる方向 が問違っていることを友達に指摘されるが、本人は 相変わらずできあがった箱を集めては上に積み重ね ることに夢中になる。結局、上記の作業をしていた 友達が準備していた箱も自分のテーブルの方へ取り 込んでしまい最後は箱の奪い合いとなった (1984.4.6)。

(4) 手の操作から道具の操作への中間的段階（不十 分な道具の使用) 
・ノコギリ引き。切りロを導き線に沿ってノコギリの 歯を動かすことを覚えると、力まかせに次々と切り 始めた。が、しばらくしてまっすぐに歯が入らない と押さえつけるようにノコギリを板面に当て、先の 動作が消滅してしまった。そこで、Tが切り出し面 だけ援助してその後を本人にまかせたが、それでも うまく切れないようでとうとう最後はハンマーのよ うにノコギリで板をたたき始めた（1985.6.15）。

・空き缶つぶしの作業。せっかく、木づちで空き缶を つぶす課題を習得したにもかかわらず友達が足で踏 みつぶしているのを見てしきりにまねようとした。 木づちは本人にとっては量産するための道具として とらえられていないようだ(1989.11.7)。

(5) 作業成果に対する自己評価の未熟さ

・初めてのボーナス。硬貨は大事に持とうとするが、 紙幣には関心が薄いようでテーブルの横に置いたま まである。結局、友達が受け取っている間に細かく ちぎって破ってしまった（1981.12.25）。

・空き午つぶしの作業を一人でする。しかしながら、 しばらく観察してみると、空き缶を一つ一つ積み木 のように並べたり近くにある水道から水を缶の中に 入れたりしながら最後に缶つぶしの作業をしていた ことが分かった（1989.11.7）。

・紙袋の結束作業補助。友達が作った紙袋を結束台に 集めて結束する作業を手伝ってもらったが、完成さ れていない紙袋まで一緒に集めて「デキタ!デキ タ!」と T に報告していた（1992.1.21）。

(6) 労働活動における直接的動機づけ

・「箱折りしょうか」と T が呼びかけると「ハコ?八 コ？」と尋礼て Tに同意を求める。さらに「ドレ? ドレ?」とTに材料を指示されるのを請う (1986.5.6)。

・朝礼後ずっと座っていたので「H 君、チラシ入れし よか」と学が誘うと自分から材料を持ってきて作業 を始めた。しばらくするとチラシを何枚も取って来 ては重ねたり袋を並べたりしていたので再び「チラ シ入れしょうか」と $\mathrm{H}$ 君に言うとまたチラシ入れの 作業が始まった（1985.7.23）。

このように、H 君の労働活動における特徵は作業成 果を適切に把握できなかったり自己の活動を対象化し 作業として受け止める力の弱さに表れていた。白石 $\left(1987^{3)}\right)$ は 2 次元形成萌芽期の特徴として対称性の 操作レベルが強まり反応が固定化されやすいと報告し ているが、発達的にこの段階に位置づけられた $\mathrm{H}$ 君の 労働活動はまさにこうした発達的特徵に規定されて現
象化されたものと言えよう。また、そうした関連は作 業集団に打ける自己中心的対人関与へと展開され、上 部連関の「ずれ」も加わって集団的不適応へとしばし ば問題化していったと思われる。しかしながら、長年 の作業指導の成果として自我の拡大を予測させる反応 が見られたり作業中に積極的な対人行動が観察された のは労働経験の中で培われた「大人の自覚」あるいは 「仕事への誇り」の表れであろう。

\section{IV . むすび}

Нечаева $\left(1964^{11)}\right.$ ) は就学前の年少児の労働特性を「目 標」「方法」「成果」が混在化された遊戯的行為とし て「過程的行為」と呼んだが、H 君の労働活動はこれ と類似した内容をもっている。目標設定においては運 ばなくてもよい物を運んだり、取らなくてもよい物を 取るなど作業課題を了解することの困難さに加えて、

(作業) 対象が変わっても活動が自動的に継続された り、逆にさ細な周囲からのノイズに反応して作業が中 断してしまうなど、本人への継続的な働きかけが無け れば作業行動が維持できなかった。また、方法におい ては「もっと楽に・上手に・早く」という合目的的な 活動の基礎として道具を使用する意図がほとんど見ら れず、スキルの獲得以上に本人の中で道具が一つの手 段として理解されていないことが示された。さらに成 果については作業成果の対価としてのボーナスの意味 を解さないばかりか、友人や指導員の評価と自己評価 の間にしばしば生じた大きな隔たりをまったく無視し てしまう傾向にあり次の課題に容易に拡延しなかっ た。結局目標を設定しそのための方法を探り目標に応 じた成果ができるように常に自己評価していくという 労働活動に扔ける基礎的な連関を成立させるための発 達的条件が整っていないと言えよう。それ故、労働活 動への「一般的動機づけ」の理解が無いまま「所与の 活動に含まれる行為の直接的動機づけ」(レオンチェ フ，19798)によって起動している H 君の労働は、一部 に強くこん跡する他者依存的関係を足掛かりに周囲か らの継続的な目標確認や目標と手段との関連づけへの 援助が展開され活動の意味が常に本人へ喚起されるこ とが重要な要素となって構成されていると考えられ る。

\section{文 献}

1) Нечаева, В. Г. (1964) Трудовое воспитание в детском саду. 藤井敏彦訳 (197I）幼児の労働教育. 明治 図書, 21-76. 
2) 西村章次 (1970) 重度精神薄弱児 (者) の行動の 発達に関する研究一臨床的観察から一. 特殊教 育学研究, 7 (3), 13-27.

3）白石恵理子 (1987) 2 次元形成萌芽期の造形活動 における対称性の発達と生活年齢効果. 人間発 達研究所紀要, 1, 15-31.

4) 田中昌人 (1980) 人間発達の科学. 青木書店.

5) 田中昌人・田中杉恵 (1984) 子どもの発達と診断 3 , 幼児期 I. 大月書店.
6) 田中昌人 (1987) 人間発達の理論. 青木書店.

7) 田中昌人 (1988) 自我の拡大から充実に向かう人 たち, 労働と人格発達, 人間発達研究所編. 全 国障害者問題研究会出版部, 169-252.

8) Леонтьев, А. Н. (1965) Проблемы, развития Психики. 松野 豊・西牟田久雄訳 (1979) 子どもの精神 発達. 明治図書, 68-86.

- 1994.4.1. 受稿, 1995.10.2 8. 受理一 